\title{
Loss of fucoid algae along a gradient of urbanisation, and structure of benthic assemblages
}

\author{
L. Mangialajo*, M. Chiantore, R. Cattaneo-Vietti \\ Dipartimento per lo Studio del Territorio e delle sue Risorse, Università degli Studi di Genova, C. ${ }^{\text {so }}$ Europa 26, \\ 16132 Genova, Italy
}

\begin{abstract}
Canopy-forming macroalgae of the genus Cystoseira are being lost in several areas of the Mediterranean Sea. Cystoseira amentacea var. stricta and C. compressa are common species in the Ligurian Sea; they are distributed in patches, but their abundance and distribution is locally variable. We investigated changes in relative cover, biomass and morphology of Cystoseira amentacea var. stricta and C. compressa with increasing urbanisation, and effects of the presence or absence of Cystoseira species on the composition and structure of understorey assemblages. C. amentacea var. stricta habitats were lost close to urban areas, while C. compressa slightly increased. The morphological characteristics of these 2 species were very variable in space and time, and did not vary with urbanisation. Assemblages lacking canopy differed markedly from Cystoseira-dominated assemblages, particularly assemblages dominated by Corallina elongata, the species most responsive to changes in habitat structure and urbanisation, which forms dense turfs in urban habitats lacking canopies. Marked species-specific differences between the assemblages dominated by the 2 Cystoseira species were detected. C. amentacea var. stricta is a key species maintaining habitat complexity and species diversity in Mediterranean rocky shores and we recommend additional conservation actions, such as habitat restoration by transplantation of this endangered species.
\end{abstract}

KEY WORDS: Cystoseira amentacea var. stricta $\cdot$ Cystoseira Compressa $\cdot$ Corallina elongata $\cdot$ Fucoid algae $\cdot$ Habitat loss $\cdot$ Structuring role $\cdot$ Urbanisation

Resale or republication not permitted without written consent of the publishe

\section{INTRODUCTION}

Canopy-forming brown algae, in particular Fucales and Laminariales, are habitat formers on understorey assemblages, modifying physical and biological factors (Reed \& Foster 1984, Ballesteros et al. 1998, Jenkins et al. 1999a,b, Bulleri et al. 2002) and leading to biological habitat amelioration (sensu Moore et al. 2007), but their loss is reported worldwide (Steneck et al. 2002, Airoldi \& Beck 2007).

The genus Cystoseira (Fucales) is represented by 45 species (Guiry \& Guiry 2007), most of them endemic to the Mediterranean Sea (Barceló et al. 2000). They represent the highest level of Mediterranean seaweed complexity, are long-lived (Clayton 1990, Ballesteros et al. 2002), can reach high biomass values (Ballesteros 1989), and dominate in several communities (Giaccone
\& Bruni 1973); therefore they are generally considered the 'Mediterranean kelps.'

Loss of low shore Cystoseira assemblages in the Mediterranean Sea has been shown in a large number of studies (for a short review see Thibaut et al. 2005). Species of Cystoseira seem to be sensitive to a variety of environmental stressors, as a consequence of which, they are now used in ecological status assessment (sensu Water Framework Directive 2000/60/EU, Ballesteros et al. 2007, Mangialajo et al. 2007). The ecological consequences of the loss of Cystoseira species on understorey assemblages, however, are little known.

In the Ligurian Sea (NW Mediterranean), Cystoseira amentacea var. stricta, (hereafter C. amentacea) and C. compressa form non-continuous belts at low shore level. They are patchily distributed, with the upper limit of C. compressa distribution generally occurring 
above that of $C$. amentacea var. stricta, but their relative abundance and distribution are locally variable, due to erratic recruitment and interactions of abiotic and biotic factors at different spatial scales (BenedettiCecchi et al. 1996, 2000). C. amentacea, endemic to the Mediterranean Sea, is very sensitive to changes in water quality (Pinedo et al. 2007, and references therein), while $C$. compressa shows a wider distribution (present also in the Atlantic Ocean) and seems to be more tolerant. It has been suggested that one of the first noticeable effects of urban wastewater pollution is the replacement of $C$. amentacea var. stricta by C. compressa (Giaccone 1993); along the Albères coast, Thibaut et al. (2005) recorded the loss of all Cystoseira spp. (including C. mediterranea, vicariant of C. amentacea), except for C. compressa. The replacement of $C$. amentacea by $C$. compressa has also been observed following large-scale experimental removals of Cystoseira canopies (mostly C. amentacea) by Benedetti-Cecchi et al. (2001).

Coastal development in Europe is among the major drivers of the loss of complex macroalgal beds, mainly due to the degradation of water quality (Airoldi \& Beck 2007). The Ligurian Sea coastline has been historically very urbanised, which has led to severe modifications of natural rocky coastline, as well as pollution, local eutrophication, and increased water turbidity. Urbanisation increases towards Genova city; which is reflected by gradients in water column characteristics (in particular an increase of nutrients and faecal bacteria, Mangialajo et al. 2007), but knowledge of the effects of urbanisation on canopy-forming macroalgae and associated species is limited. The aim of this

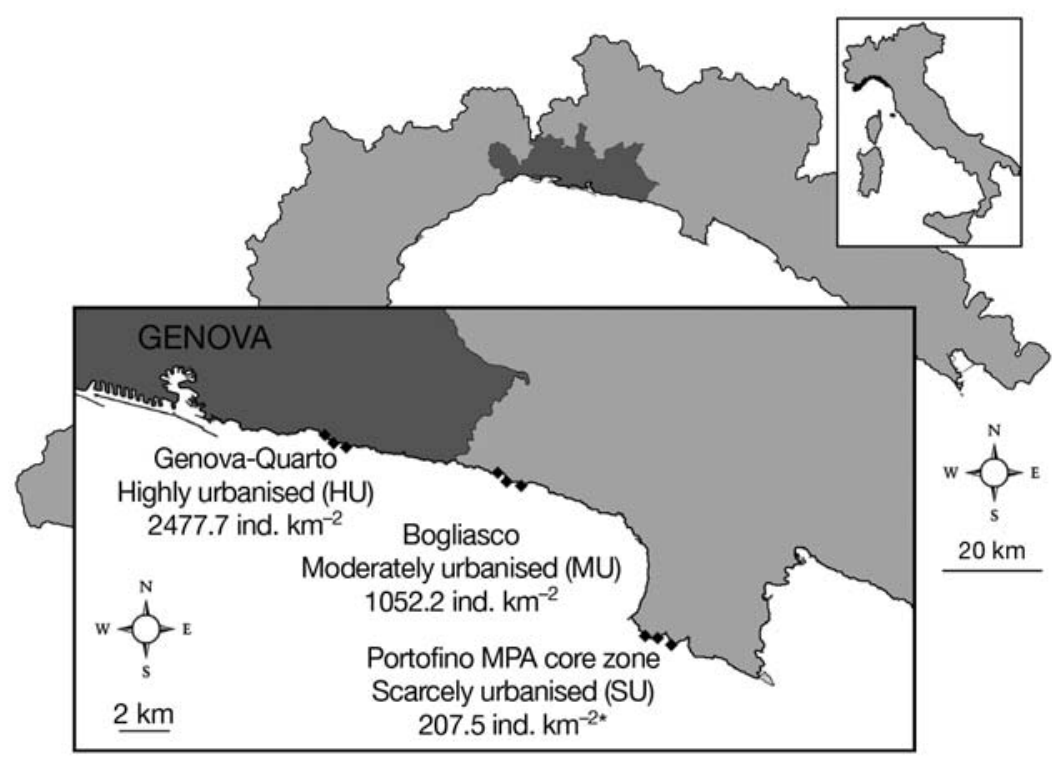

Fig. 1. Location of the 3 shores along the urban gradient near Genova city, together with inhabitant densities; ${ }^{*}$ density at Portofino village, $5 \mathrm{~km}$ east of the core zone study was to test whether the relative cover, biomass and morphology of Cystoseira amentacea and C. Compressa changed along a gradient of urbanisation of the coastline, and whether the composition and structure of understorey assemblages differed in relation to the presence or absence of $C$. amentacea and C. compressa, taking into account any such differences along the same gradient of urbanisation.

\section{MATERIALS AND METHODS}

Sampling. The study was performed in a microtidal environment (tidal amplitude around $30 \mathrm{~cm}$ ) in the typical Mediterranean infralittoral fringe (Pérès \& Picard 1964). Three sections of shoreline about 1.5 to $2 \mathrm{~km}$ long, characterised by the presence of both Cystoseira amentacea and C. compressa, were selected along an increasing gradient of inhabitant density and distance from the city of Genova (Fig. 1), as in Mangialajo et al. (2007): Genova Quarto (highly urbanised, HU), Bogliasco (moderately urbanised, MU) and Portofino (scarcely urbanised, SU). All sections have natural carbonatic rocky bottoms (limestone in HU and MU, pudding stone in SU) and similar geographical exposition, fetch and exposure to wave action. Within each section, we chose at random 3 sites about 300 to $500 \mathrm{~m}$ long and hundreds of meters apart, and for each site we considered 3 types of habitats: (1) C. amentacea, (2) C. compressa, (3) absence of fucoid algae. Percentage cover of C. amentacea and C. compressa was estimated along 10 independent $20 \mathrm{~m}$ transects at each site in May 2004 by quantifying the proportion of coastline covered by dense clumps of either C. amentacea or C. compressa, or lacking fucoids.

Biomass and morphological features of Cystoseira amentacea and C. compressa were quantified in patches where populations showed high densities (canopy cover between 80 and $100 \%$ ). In order to limit disturbance to these endangered species, primary axes were cut near the holdfast in 3 replicate $400 \mathrm{~cm}^{2}$ plots for each site. The surface covered by holdfasts was visually quantified in situ, while lengths of 10 randomly chosen axes and primary branches were measured in the laboratory. Biomass was calculated as dry weight (after $48 \mathrm{~h}$ at $70^{\circ} \mathrm{C}$ ). To avoid overweight due to epiphytes (mostly articulated Corallinales), branches and axes were roughly cleaned with a pair of tweezers, slightly centrifuged and treated with hydrochloric acid ( $4 \%$ ) for $60 \mathrm{~min}$. 
The composition of understorey assemblages in each habitat was analysed by sampling three $400 \mathrm{~cm}^{2}$ plots at each site. Percentage cover of understorey species was visually estimated by using a frame with twentyfive $4 \times 4 \mathrm{~cm}$ subquadrats (Meese \& Tomich 1992, Dethier et al. 1993) after the removal of canopies of Cystoseira. Mobile animals (except limpets) were not considered. When the identification to the species level was not possible in situ, specimens were collected and identified in the laboratory; in order to reduce the sampling effort, some organisms were grouped in taxonomic or morphological groups, hereafter called taxa.

Due to the high seasonal variability of biomass of fucoids and associated algal diversity, the studies of biomass, morphological features, and structure of assemblages were conducted twice, in spring (May 2004), when biomass and algal diversity are highest, and in autumn (October 2004), at the beginning of the Cystoseira resting period.

Data analysis. The full models (including the factor Time) in both univariate and multivariate analyses would have not provided the correct denominators to test the effects of Habitat and Urbanisation, and of their interaction. In order to avoid complicated pooling procedures, we chose to analyse the 2 sampling times separately, because temporal variability is not specifically addressed in our hypotheses.

For the univariate analyses on biomass and holdfast cover, for each sampling time the ANOVA model included 2 factors: Urbanisation (fixed, orthogonal) and Site (random, nested in Urbanisation). Analyses on axis and branch lengths included the additional factor, Plot (random, nested in Site).

Changes in the composition of understorey assemblages were tested by multivariate analyses. For each sampling time, the model included 3 factors: Habitat (fixed, orthogonal), Urbanisation (fixed, orthogonal) and Site (random, nested in Urbanisation). Differences among assemblages were tested by non-parametric ANOVA (PERMANOVA, Anderson 2001) on a Bray-Curtis similarity matrix calculated on squareroot transformed data. PERMANOVA $\mathrm{p}$ values were obtained from Monte Carlo asymptotic-permutation distributions (Anderson \& Millar 2004). The relative importance of each factor in the analysis was assessed using estimates of the magnitude of effect sizes of fixed factors, based on mean squares of the full model (Underwood 1997, Anderson \& Millar 2004), expressed as the ratio among the effect size of each fixed factor $\left(\theta^{2}{ }_{i}\right)$ and the sum of the effect sizes of all fixed factors and their interactions. In our case, the factor magnitude was expressed by the formula $\theta_{\mathrm{i}}^{2} / \Sigma\left(\theta_{\mathrm{Ha}}^{2}+\theta_{\mathrm{Ur}}^{2}+\theta_{\mathrm{Ha} \times \mathrm{Ur}}^{2}\right)$, where i corresponds, alternatively, to Habitat (Ha), Urbanisation (Ur) or their interaction $(\mathrm{Ha} \times \mathrm{Ur})$.
Multivariate patterns of distribution were plotted using a principal coordinates analysis (PCO, Anderson 2003) on Site centroids, while SIMPER analysis was performed to identify the species most responsible for the differences between the 3 habitats. Species diversity was estimated as $\log _{2}$ based Shannon-Wiener diversity index $\left(H^{\prime}\right.$, Shannon \& Weaver 1949) and ANOVA was applied to test for significant effects of Habitat and Urbanisation. All the multivariate analyses were performed using PRIMER software (Clarke \& Gorley 2006).

\section{RESULTS}

Percentage cover of habitats dominated by Cystoseira amentacea or C. compressa and habitats lacking fucoids at the 3 shores along the urbanisation gradient are reported in Fig. 2. Percentage of cover by C. amentacea decreased along the urbanisation gradient from nearly $50 \%$ at SU to less than $10 \%$ at HU, while percentage of cover by C. compressa showed the opposite trend, increasing from less than $10 \%$ cover at SU to about $20 \%$ at HU. Percentage of habitats lacking fucoids was high all along the urbanisation gradient, exceeding $70 \%$ of rocky bottoms at HU.

While overall canopy cover changed notably along the urbanisation gradient, the biomass or morphological characteristics of the 2 species of Cystoseira within each habitat did not seem to vary as much (Fig. 3, Table 1). The only exception was axis length of C. Compressa, which significantly increased from SU to HU in both May and October. Also in October, length of branches of $C$. compressa increased slightly but significantly from SU to HU; this pattern was not observed in May (Table 1, SNK tests). Overall, biomass and branch length showed high variability at the lowest spatial

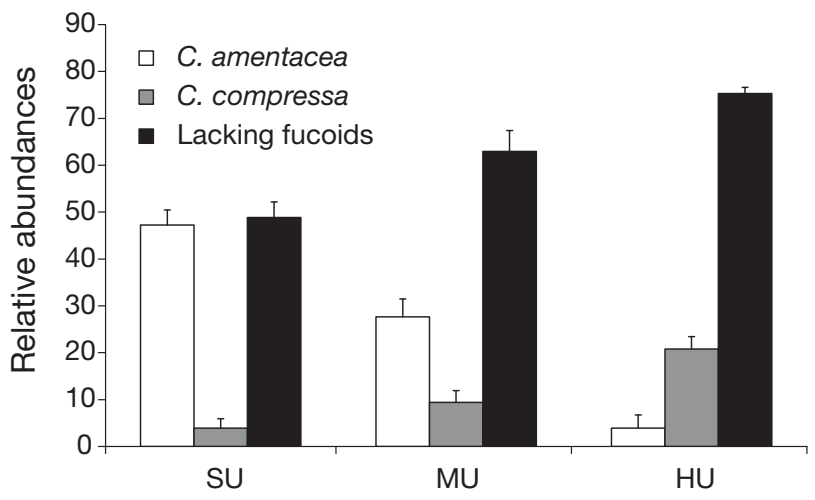

Fig. 2. Cystoseira amentacea and C. compressa. Relative abundance and habitats lacking fucoids along the urbanisation gradient: scarcely urbanised, $\mathrm{SU}$; moderately urbanised, MU; highly urbanised, HU (error bars: SE) 

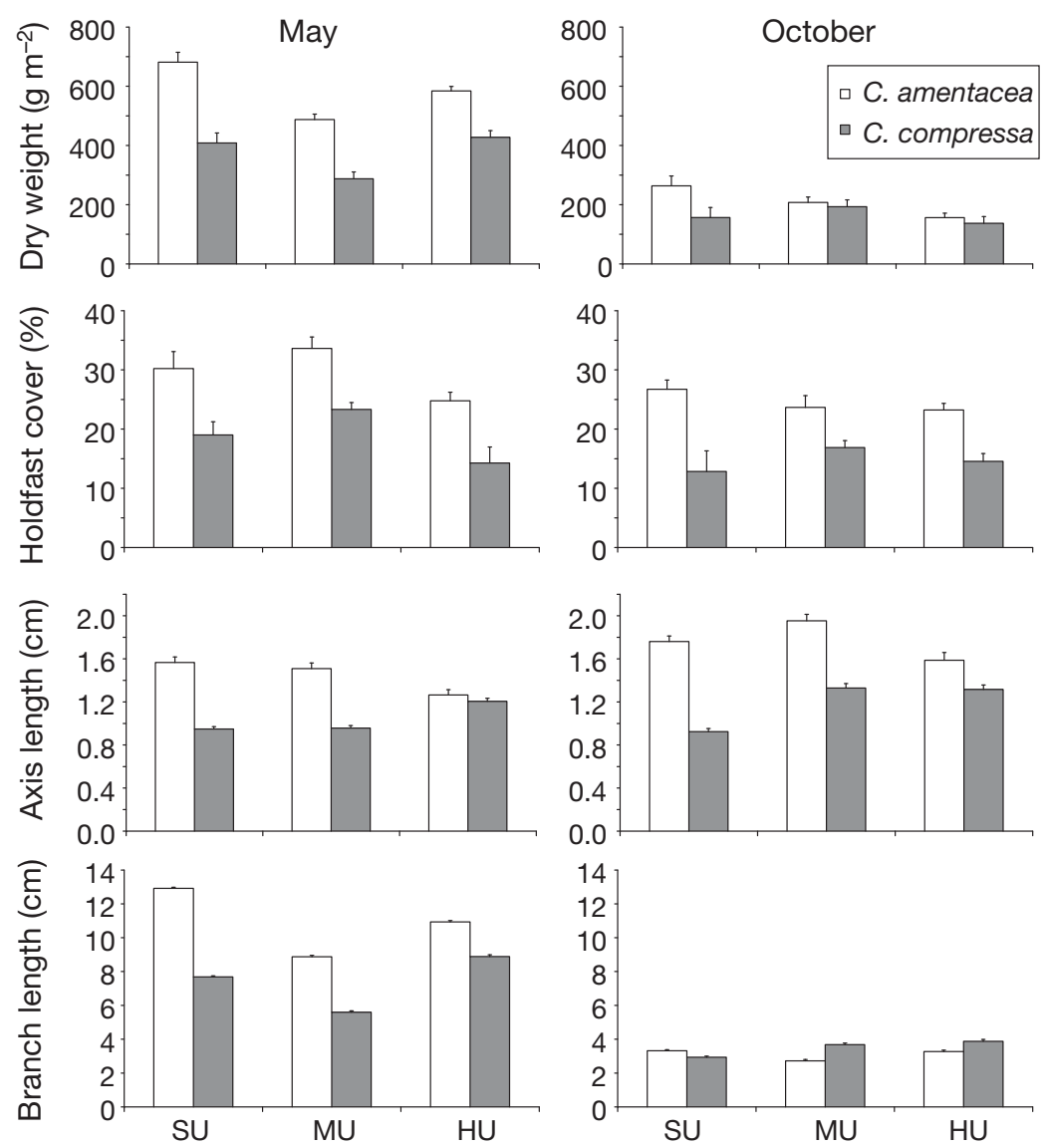

Fig. 3. Cystoseira amentacea and C. compressa. Biomass and morphological features along the urbanisation gradient. Abbreviations as in Fig. 2 (error bars: SE)

while the effects of habitat varied among sites; nevertheless, at all sites, the strongest differences were always found between habitats dominated by C. amentacea and habitats lacking fucoids (Table 5). C. compressa habitat seemed to represent an intermediate state, being in some cases not significantly different from the $C$. amentacea habitat and in other cases not significantly different from habitat lacking fucoids. The relative magnitude of the 2 main fixed factors (Habitat and Urbanisation) at both sampling times highlighted the larger effect of Habitat (0.52 in May and 0.66 in October) in affecting variability in the understorey assemblages. Urbanisation effect was lower at both sampling times (0.31 in May and 0.28 in October) and the interaction between the 2 factors had the lowest weight (0.18 in May and 0.06 in October).

The relevance of the 2 factors is portrayed by PCO of site centroids (Fig. 4). The species that mostly drove the distribution of points along this axis was Corallina elongata (together with Hypnea musciformis in October), which was associated with habitats devoid of fucoids in HU. In contrast, invertebrates, encrusting corallinales

scales (Site and Plot, respectively) and between the 2 sampling times. In May, C. amentacea showed longer branches and axes, and higher holdfast cover (and consequently, higher biomass) than C. compressa, while in October there were smaller differences between the 2 species, especially for branch length and biomass.

Overall, 83 taxa were visually sampled in the 3 assemblages; they were grouped in 52 variables for the data analysis (Table 2). PERMANOVA (Table 3) showed significant differences in the structure of understorey assemblages as a function of both Habitat and Urbanisation. In May, an interaction between these 2 terms was recorded, showing that the structure of the understorey assemblage always differed significantly between habitats dominated by any Cystoseira spp. and habitats lacking canopies, while differences between the 2 canopies of Cystoseira were significant only at MU (Table 4). The structure of understorey assemblages in habitats dominated by either of the 2 Cystoseira species was always significantly different among the 3 levels of urbanisation, while in habitats lacking canopies, it was more homogeneous (Table 4). In October a strong urbanisation effect was recorded, and other light-sensitive algae (e.g. Valonia utricolaris and Pterocladiella capillacea) were associated to Cystoseira amentacea habitats, especially in SU. The second axis was mostly driven by photophilic algae, including species belonging to the genus Dictyota and to the Laurencia complex, which were associated with habitats lacking fucoids in SU. The SIMPER analysis (Table 6) highlighted that Corallina elongata was the species mostly contributing to discrimination among the different habitats and urbanisation levels. Also, thin, articulated and encrusting corallinales, Hypnea musciformis, mussels, barnacles and vermetids contributed to among group dissimilarity.

The abundances of Corallina elongata and of invertebrates are reported in Fig. 5 and the corresponding ANOVA in Table 7. At both sampling times, Corallina elongata increased from SU to HU, while invertebrates showed the opposite pattern, particularly in May. Corallina elongata was by far the most abundant species in habitats lacking fucoids (reaching $>90 \%$ of cover at HU in May) and its abundance significantly decreased in habitats of Cystoseira compressa and even more in habitats of Cystoseira amentacea, where it reached values 


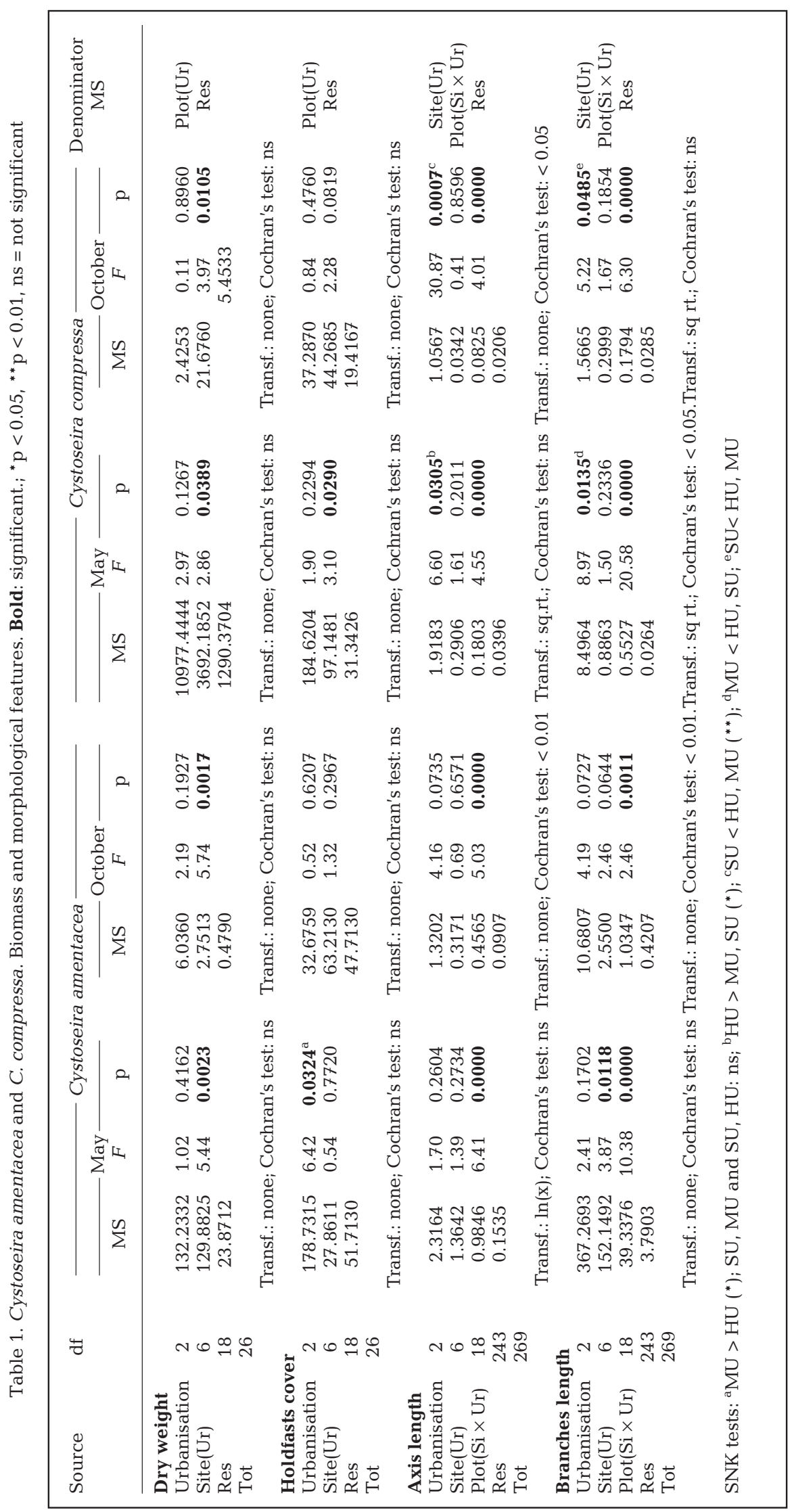

near $5 \%$ at SU (Fig. 5). Invertebrates were inversely affected by habitat, being most abundant in habitats of Cystoseira amentacea and significantly decreasing in habitats of Cystoseira compressa and even more in habitats lacking fucoids. In May, invertebrates decreased linearly from SU to HU, while in October, although always significantly less abundant at $\mathrm{HU}$, invertebrates were more abundant at MU than SU (Fig. 5). This pattern was mostly driven by mussels (SU: $3.5 \% \pm 1.3$; MU: $6.9 \% \pm 2.1$; HU: $2.8 \% \pm 0.9)$.

Overall diversity of understorey assemblages decreased significantly as a function of both Urbanisation (maximal diversity at SU, minimal at $\mathrm{HU}$ ) and Habitat (maximal diversity in habitats of C. amentacea, minimal in habitats lacking canopies, Fig. 6). In May (period of maximum algal development in the Mediterranean Sea), there was an interaction between the 2 factors (Table 8), which can be explained by lack of differences between the 2 Cystoseira habitats at SU.

\section{DISCUSSION}

Several factors have been suggested to trigger the loss of large brown algae, including urbanisation and eutrophication (Munda 1993, Benedetti-Cecchi et al. 2001, Soltan et al. 2001), increase in water turbidity and sedimentation (Vogt \& Schramm 1991, Eriksson et al. 2002, Airoldi 2003, Schiel et al. 2006), overgrazing (Jenkins et al. 1999a,b, Benedetti-Cecchi et al. 2000, Steneck et al. 2002, Thibaut et al. 2005, Hereu 2006) and climate change (Serio et al. 2006, Moore et al. 2007). While this study is correlative and therefore cannot reveal cause-effect relationships, urbanisation remains the most plausible explanation for the observed patterns, highlighting that some Cystoseira spp. are more sensitive than others to coastal urbanisation. Our results indicate that $C$. 
Table 2. Taxa found with visual census and their grouping for data treatment. Taxa reported in parentheses were identified in the laboratory

\begin{tabular}{|c|c|c|}
\hline Taxon & Species & Acronym \\
\hline Ocrophyta & $\begin{array}{l}\text { Colpomenia sinuosa } \\
\text { Filamentous phaeophyta (Sphacelaria tribuloides) } \\
\text { Dictyota spp. (D. dichotoma, D. fasciola) } \\
\text { Dictyopteris polypodioides } \\
\text { Stypocaulon scoparium } \\
\text { Taonia atomaria } \\
\text { Padina pavonica }\end{array}$ & $\begin{array}{l}\text { Col } \\
\text { FP } \\
\text { Dic } \\
\text { D.po } \\
\text { Sty } \\
\text { Tao } \\
\text { Pad }\end{array}$ \\
\hline Chlorophyta & $\begin{array}{l}\text { Bryopsis duplex } \\
\text { Caulerpa racemosa } \\
\text { Cladophora spp. (C. albida, C. coelothrix, C. hutchinsiae, C. laetevirens) } \\
\text { Filamentous chlorophyta (Flabellia petiolata }{ }^{\text {a }} \text { Pseudochlorodesmis furcellata) } \\
\text { Ulva spp. (U. compressa, U. laetevirens) } \\
\text { Valonia utricularis }\end{array}$ & $\begin{array}{l}\text { Bry } \\
\text { Cau } \\
\text { Cla } \\
\text { FC } \\
\text { Ulv } \\
\text { Val }\end{array}$ \\
\hline Rhodophyta & $\begin{array}{l}\text { Apoglossum ruscifolium } \\
\text { Chondracanthus acicularis } \\
\text { Chondria spp. (C. boryana, C. capillaris, C. dasyphylla) } \\
\text { Corallina elongata } \\
\text { Encrusting corallinales (Lithophyllum incrustans, Neogoniolithon brassica-florida) } \\
\text { Filamentous rhodophyta (Boergeseniella fruticulosa, Callithamnion granulatum, C. tetragonum, } \\
\text { C. rubrum, Dasya cfr corymbifera, Falkenbergia rufolanosa, Ceramium ciliatum, } \\
\text { Feldmannophycus rayssiae, Lophosiphonia cristata, L. obscura, Polysiphonia spp., } \\
\text { Pterosiphonia parasitica) } \\
\text { Gastroclonium clavatum } \\
\text { Grateloupia filicina } \\
\text { Hypnea musciformis } \\
\text { Laurencia complex - cylindrical (L. intricata, L. obtusa, Chondrophycus thuyoides) } \\
\text { Laurencia complex - flat (Osmundea truncata, O. verlaquei) } \\
\text { Lithophyllum byssoides } \\
\text { Peyssonnelia spp. } \\
\text { Porphyra spp. (P. leucosticta, P. umbelicalis) } \\
\text { Pterocladiella capillacea } \\
\text { Rhodymenia ardissonei } \\
\text { Schottera nicaeensis } \\
\text { Schyzimenia dubi } \\
\text { Scinaia furcellata } \\
\text { Small Gelidium like (Gelidiella pannosa, Gelidium crinale, G. pusillum) } \\
\text { Thin articulated corallinales (Amphiroa rigida, Haliptilon virgatum, Jania corniculata, J. rubens) } \\
\text { Wrangelia penicillata }\end{array}$ & $\begin{array}{l}\text { Gas } \\
\text { Gra } \\
\text { Hyp } \\
\text { LCC } \\
\text { LCF } \\
\text { Lit } \\
\text { Pey } \\
\text { Por } \\
\text { Pte } \\
\text { Rho } \\
\text { Scho } \\
\text { Schy } \\
\text { Sci } \\
\text { Gel } \\
\text { TAC } \\
\text { Wra }\end{array}$ \\
\hline Mixed algal OTU & Encrusting non corallinales (Aglaozonia stadium, Hildenbrandia spp., Ralfsia spp.) & ENC \\
\hline Anellida & $\begin{array}{l}\text { Gregarian serpulids (Filograna sp.) } \\
\text { Individual serpulids }\end{array}$ & $\begin{array}{l}\text { GS } \\
\text { IS }\end{array}$ \\
\hline Arthropoda & Barnacles (Balanus perforatus) & Bar \\
\hline Bryozoa & Encrusting bryozoans (Schizobrachiella sanguinea) & EB \\
\hline Cnidaria & $\begin{array}{l}\text { Actiniarians } \\
\text { Aglaophenids-plumularids (Aglaophenia kirchenpaueri) } \\
\text { Corynactis viridis } \\
\text { Hydrozoans (other) } \\
\text { Paracoryne huvey }\end{array}$ & $\begin{array}{l}\text { Act } \\
\text { Agl } \\
\text { C.vir } \\
\text { Hyd } \\
\text { Par }\end{array}$ \\
\hline Mollusca & $\begin{array}{l}\text { Gastrochaena dubia } \\
\text { Mussels (Mytilus galloprovincialis, Mytilaster spp.) } \\
\text { Limpets (Patella spp., Fissurella spp.) } \\
\text { Vermetids (Vermetus triquetrus) }\end{array}$ & $\begin{array}{l}\text { G.du } \\
\text { Mus } \\
\text { Lim } \\
\text { Ver }\end{array}$ \\
\hline Porifera & $\begin{array}{l}\text { Cliona spp. } \\
\text { Encrusting sponges }\end{array}$ & $\begin{array}{l}\text { Cli } \\
\text { ES }\end{array}$ \\
\hline Tunicata & Didemnids (Didemnum maculosum) & Did \\
\hline
\end{tabular}


Table 3. PERMANOVA on understorey benthic assemblages. Bold: significant p values. Cystoseira amentacea habitat $=\mathrm{CA}_{i}$ C. compressa habitat $=\mathrm{CC}$ habitat lacking fucoids $=\mathrm{NC}$

\begin{tabular}{|c|c|c|c|c|c|c|c|c|}
\hline \multirow{2}{*}{ Source of variation } & \multirow[t]{2}{*}{$\mathrm{df}$} & \multicolumn{3}{|c|}{ May } & \multicolumn{2}{|r|}{ October } & \multirow[b]{2}{*}{$\mathrm{p}$} & \multirow{2}{*}{ Denominator MS } \\
\hline & & MS & $F$ & $\mathrm{p}$ & MS & $F$ & & \\
\hline Habitat & 2 & 25241.426 & 26.4851 & 0.0001 & 22545.9773 & 22.0482 & 0.0001 & Ha × Si(Ur) \\
\hline Urbanisation & 2 & 16166.822 & 9.2084 & 0.0001 & 10839.5802 & 5.8641 & $0.0009^{c}$ & $\mathrm{Si}(\mathrm{Ur})$ \\
\hline Site(Ur) & 6 & 1755.669 & 2.5099 & 0.0016 & 1848.463 & 3.4403 & 0.0001 & Res \\
\hline $\mathrm{Ha} \times \mathrm{Ur}$ & 4 & 3749.058 & 3.9338 & $0.0016^{a}$ & 1684.061 & 1.6469 & 0.1044 & $\mathrm{Ha} \times \mathrm{Si}(\mathrm{Ur})$ \\
\hline $\mathrm{Ha} \times \mathrm{Si}(\mathrm{Ur})$ & 12 & 953.042 & 1.3625 & 0.0888 & 1022.5758 & 1.9032 & $0.0028^{b}$ & Res \\
\hline Residual & 54 & 699.499 & & & 537.2916 & & & \\
\hline
\end{tabular}

A posteriori comparisons: ${ }^{\mathrm{a}}$ Habitat $\times$ Urbanisation: see Table $4 ;{ }^{b}$ Habitat $\times$ Site $(U r)$ : see Table 5 ; ${ }^{c}$ Urbanisation: SU, MU: $\mathrm{p}=0.2148 ; \mathrm{SU}, \mathrm{HU}: \mathrm{p}=0.0139 ; \mathrm{MU}, \mathrm{HU}: \mathrm{p}=0.0130$

Table 4. A posteriori comparisons ( $\mathrm{p}$ values) for the significant Habitat $\times$ Urbanisation interaction (May, Table 3)

\begin{tabular}{|lccccccc|}
\hline & \multicolumn{3}{c}{ Factor Habitat patch } & & \multicolumn{2}{c|}{ Factor Urbanisation } \\
& SU & \multicolumn{2}{c}{ MU } & HU & CA & CC \\
\hline CA, CC & 0.1187 & 0.0055 & 0.0873 & SU, MU & 0.0185 & 0.0136 \\
CA, NC & 0.0049 & 0.0019 & 0.0092 & SU, HU & 0.0155 & 0.0034 & 0.0583 \\
CC, NC & 0.0185 & 0.0281 & 0.0141 & MU, HU & 0.0205 & 0.0291 & 0.4409 \\
\hline
\end{tabular}

Table 5. A posteriori comparisons ( $\mathrm{p}$ values) for Habitat $\times$ Site(Ur) significant interaction (October, Table 3 ); test for Habitat effect within each level of factor Site(Ur). Levels: Site A, B and C within each level of factor Urbanisation (SU, MU and HU)

\begin{tabular}{|lccccccccc|}
\hline & SU A & SU B & SU C & MU A & MU B & MU C & HU A & HU B & HU C \\
\hline CA, CC & 0.0386 & 0.0506 & 0.3150 & 0.0221 & 0.0148 & 0.0121 & 0.1941 & 0.0176 & 0.2859 \\
CA, NC & 0.0151 & 0.0208 & 0.0024 & 0.0041 & 0.0027 & 0.0016 & 0.0131 & 0.0012 & 0.0402 \\
CC, NC & 0.0976 & 0.0309 & 0.0198 & 0.3452 & 0.0503 & 0.0206 & 0.0153 & 0.0091 & 0.1882 \\
\hline
\end{tabular}
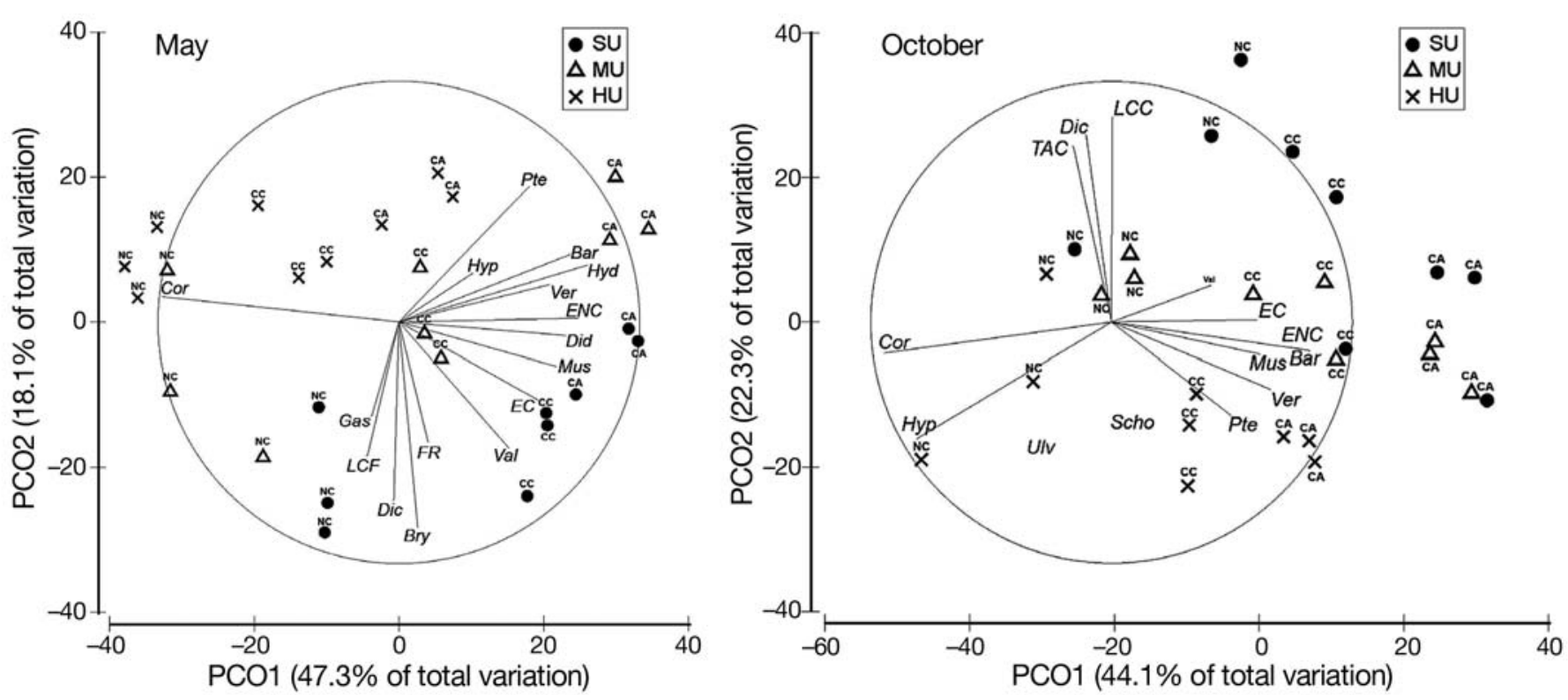

Fig. 4. PCO of site centroids. Abbreviations for urbanisation levels as in Fig. 2. Cystoseira amentacea habitats $=\mathrm{CA}_{;}$C. compressa habitats $=\mathrm{CC}$, habitats lacking fucoids $=$ NC. Other abbreviations: see Table 2 
amentacea habitats were lost close to urban areas, in agreement with previous observations (Thibaut et al. 2005, Arèvalo et al. 2007 and references therein), while C. compressa slightly increased, as also observed by Giaccone (1993) and Thibaut et al. (2005). The slightly increased abundance of $C$. compressa close to urban areas could be due to reduced competition with $C$. amentacea.

While habitat cover changed notably along the urbanisation gradient, the biomass and morphological characteristics of the 2 species of Cystoseira did not vary as much, and we observed a high variability at small spatial scales and between times, as is common in Cystoseira spp. (Ballesteros 1988, Pizzuto et al. 1995). Only the length of axes of $C$. compressa increased towards the most urbanised shore. This could be related to possible release from competition with $C$. amentacea, but we cannot exclude effects of other environmental factors. Manipulative experiments involving cross-transplantation of the 2 species will be necessary to clarify the causes of these patterns.

Overall, the results of the present study suggest that while loss of Cystoseira amentacea is a good indicator of anthropogenic effects related to coastal urbanisation, $C$. compressa probably is not, due to its more complex responses. Biomass and morphological features of the 2 species cannot be considered good indicators due to their high variability in space and time.

Benthic understorey assemblages were significantly affected by changes in the distribution of Cystoseira species along the urbanisation gradient. Lack of any of the 2 species of Cystoseira was the factor mostly affecting assemblage structure, but there were also marked differences between the 2 Cystoseira habitats. The species

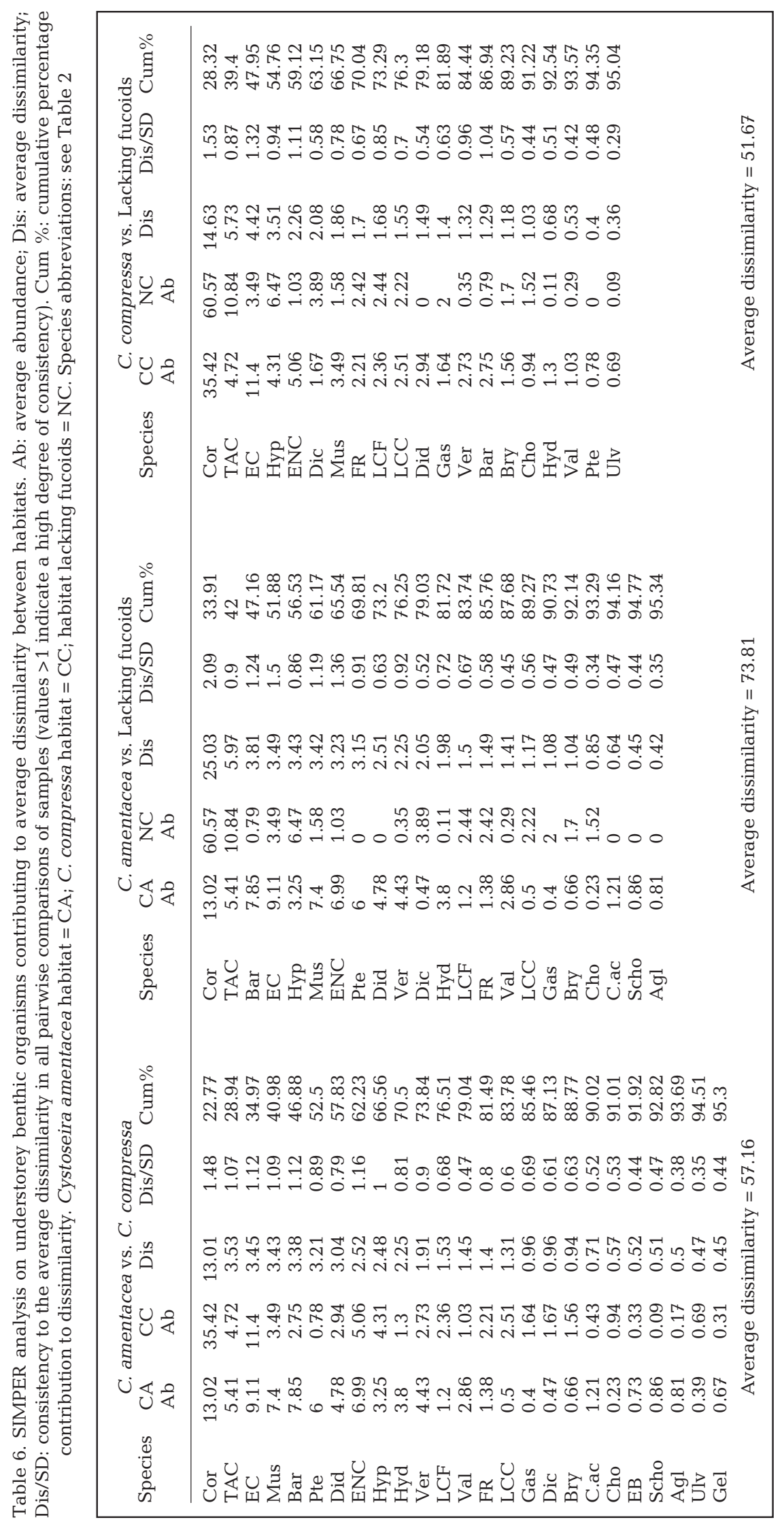




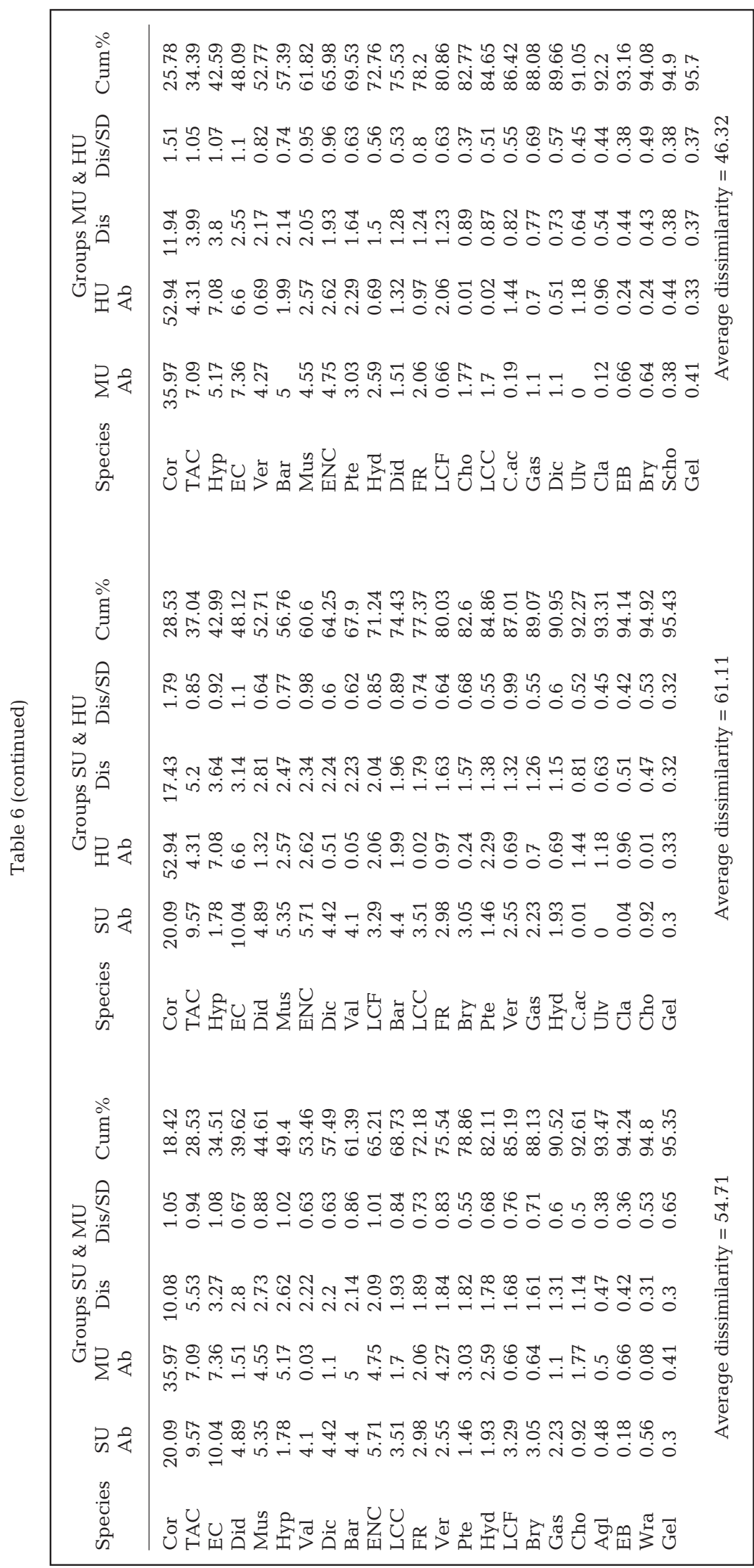

that most responded to changes in habitat structure and urbanisation was Corallina elongata, a common species in the northwestern Mediterranean Sea (see also Benedetti-Cecchi \& Cinelli 1992, Benedetti-Cecchi et al. 2001). This species reached very high cover $(>90 \%)$ in habitats lacking fucoids at the highly urbanised shore, while at the scarcely urbanised shore it was less abundant ( $<50 \%$ cover), and became nearly absent in Cystoseira amentacea habitats $(<5 \%$ cover $)$, where it was replaced by invertebrates and lightsensitive algae. The greater diversity of understorey species under fucoid canopies, especially in $C$. amentacea habitats, suggests that these species may have a particularly important role in the amelioration of biological habitat (sensu Moore et al. 2007), preventing dominance by $C$. elongata and offering shelter to a variety of species. Conversely, canopies of Cystoseira compressa did not seem to exert such a strong effect on understorey species and were less effective in preventing colonisation by C. elongata. Algal turfs, including those originated by $C$. elongata have been suggested to inhibit the recruitment of many canopy-forming algae (Kennelly 1987, Airoldi 1998, Connell 2005). Although the concept of alternate stability is controversial (Scheffer et al. 2001 and references therein), turfs of corallinales and canopy algae have been proposed as alternative states in temperate reefs (Airoldi 2003, Connell 2005); this study supports the hypothesis that coastal urbanisation could be a driver of shifts between canopy habitats and turfs.

Science and management demand simplified representation of complex systems, but such simplification depends on correct understanding of natural history (Dayton \& Sala 2001, Dayton 2003). The results of the present study strongly indicate that it is important to differentiate among different species of Cystoseira in ecological studies, not only because of their different responses to anthropogenic impacts, but also because they seem to have different 'engineering' effects on understorey assemblages. Therefore, species 


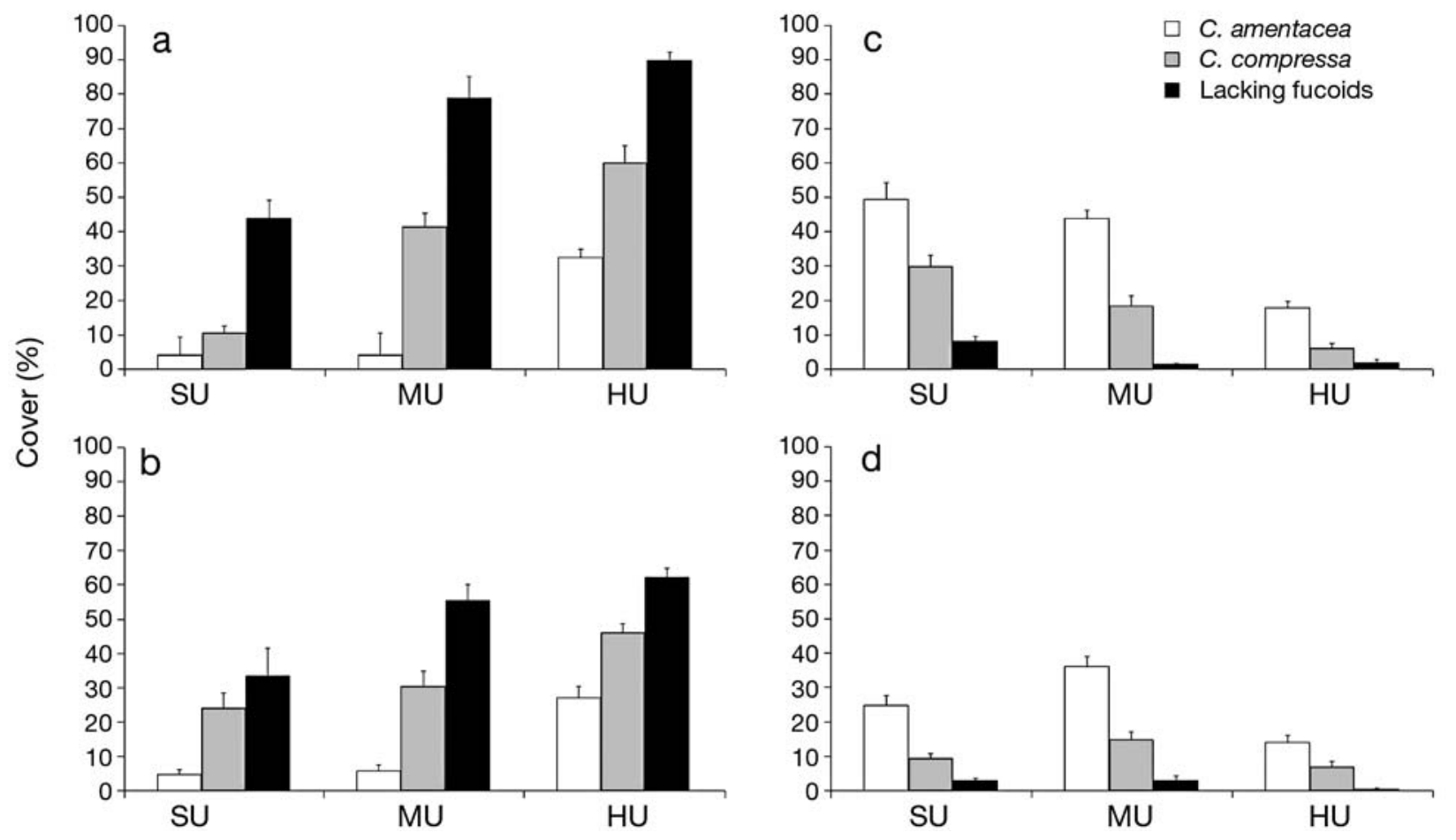

Fig. 5. Percentage cover of Corallina elongata (a: May, b: October) and invertebrates (c: May, d: October). Abbreviations as in Fig. 2 (error bar: SE)

Table 7. ANOVA of percentage cover in Corallina elongata and invertebrates. Bold: significant; ${ }^{*} \mathrm{p}<0.05,{ }^{* *} \mathrm{p}<0.01, \mathrm{~ns}=\mathrm{not}$ significant

\begin{tabular}{|c|c|c|c|c|c|c|c|c|}
\hline \multirow{2}{*}{ Source of var. } & \multirow{2}{*}{$\mathrm{df}$} & \multicolumn{3}{|c|}{-May } & \multicolumn{3}{|c|}{ October } & \multirow{2}{*}{ Denominator MS } \\
\hline & & MS & $F$ & $\mathrm{p}$ & MS & $F$ & $\mathrm{p}$ & \\
\hline \multicolumn{9}{|c|}{ Corallina elongata } \\
\hline Habitat & 2 & 22342.57 & 135.92 & 0.0000 & 9708.88 & 52.24 & $0.0000^{b}$ & $\mathrm{Ha} \times \mathrm{Si}(\mathrm{Ur})$ \\
\hline Urbanisation & 2 & 11547.56 & 38.36 & 0.0004 & 4057.19 & 12.39 & $0.0074^{\mathrm{c}}$ & $\mathrm{Si}(\mathrm{Ur})$ \\
\hline Site(Ur) & 6 & 301.03 & 2.29 & 0.0484 & 327.51 & 2.34 & 0.0439 & Res \\
\hline $\mathrm{Ha} \times \mathrm{Ur}$ & 4 & 845.52 & 5.14 & $0.0120^{\mathrm{a}}$ & 282.79 & 1.52 & 0.2575 & $\mathrm{Ha} \times \mathrm{Si}(\mathrm{Ur})$ \\
\hline $\mathrm{Ha} \times \mathrm{Si}(\mathrm{Ur})$ & 12 & 164.38 & 1.25 & 0.2750 & 185.84 & 1.33 & 0.2294 & Res \\
\hline Residuals & 54 & 131.48 & & & 139.73 & & & \\
\hline \multirow[t]{2}{*}{ Tot } & 80 & \multirow{2}{*}{\multicolumn{3}{|c|}{ Transf.: none; Cochran's test: ns }} & & & & \\
\hline & & & & & \multicolumn{3}{|c|}{ Transf.: none; Cochran's test: ns } & \\
\hline \multicolumn{9}{|l|}{ Invertebrates } \\
\hline Habitat & 2 & 7526.94 & 71.24 & 0.0000 & 3653.6759 & 148.50 & 0.0000 & $\mathrm{Ha} \times \mathrm{Si}(\mathrm{Ur})$ \\
\hline Urbanisation & 2 & 2874.44 & 48.83 & 0.0002 & 798.1759 & 15.63 & 0.0042 & $\mathrm{Si}(\mathrm{Ur})$ \\
\hline Site(Ur) & 6 & 58.87 & 1.31 & 0.2692 & 51.0617 & 1.66 & 0.1500 & Res \\
\hline $\mathrm{Ha} \times \mathrm{Si}$ & 4 & 528.89 & 5.01 & $0.0132^{d}$ & 237.1852 & 9.64 & $0.0010^{\mathrm{e}}$ & $\mathrm{Ha} \times \mathrm{Si}(\mathrm{Ur})$ \\
\hline $\mathrm{Ha} \times \mathrm{Si}(\mathrm{Ur})$ & 12 & 105.65 & 2.35 & 0.0165 & 24.6034 & 0.80 & 0.6510 & Res \\
\hline Residuals & 54 & 44.98 & & & 30.8457 & & & \\
\hline Tot & 80 & & & & & & & \\
\hline & & \multicolumn{3}{|c|}{ Transf.: none; Cochran's test: ns } & \multicolumn{3}{|c|}{ Transf.: none; Cochran's test: ns } & \\
\hline \multicolumn{9}{|c|}{ 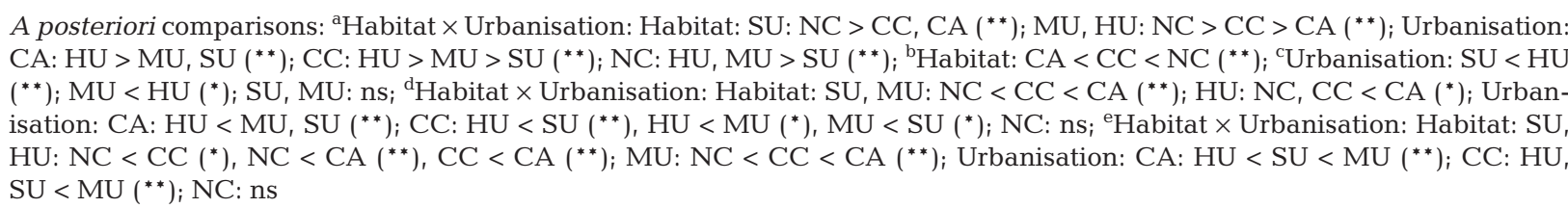 } \\
\hline
\end{tabular}


Table 8. ANOVA on Shannon-Wiener diversity index $\left(H^{\prime}\right)$. Cystoseira amentacea habitats $=\mathrm{CA}_{i}$ C. compressa habitats $=\mathrm{CC}$; habitats lacking fucoids $=$ NC. Bold: significant; ${ }^{*} \mathrm{p}<0.05,{ }^{* *} \mathrm{p}<0.01, \mathrm{~ns}=$ not significant

\begin{tabular}{|c|c|c|c|c|c|c|c|c|}
\hline \multirow{2}{*}{\multicolumn{2}{|c|}{ Source of variation }} & \multicolumn{3}{|c|}{ May - } & \multicolumn{2}{|r|}{ October } & \multirow[b]{2}{*}{$\mathrm{p}$} & \multirow{2}{*}{ Denominator MS } \\
\hline & df & MS & $F$ & $\mathrm{p}$ & MS & $F$ & & \\
\hline Habitat & 2 & 11.0337 & 89.1749 & 0.0000 & 4.6460 & 60.8895 & $0.0000^{b}$ & $\mathrm{Ha} \times \mathrm{Si}(\mathrm{Ur})$ \\
\hline Urbanisation & 2 & 4.9749 & 20.2485 & 0.0021 & 1.1582 & 13.0984 & $0.0065^{\mathrm{c}}$ & $\mathrm{Si}(\mathrm{Ur})$ \\
\hline Site(Ur) & 6 & 0.2457 & 2.8361 & 0.0179 & 0.0884 & 2.2656 & 0.0506 & Res \\
\hline $\mathrm{Ha} \times \mathrm{Ur}$ & 4 & 0.7050 & 5.6976 & $0.0083^{a}$ & 0.1111 & 1.4565 & 0.2755 & $\mathrm{Ha} \times \mathrm{Si}(\mathrm{Ur})$ \\
\hline $\mathrm{Ha} \times \mathrm{Si}(\mathrm{Ur})$ & 12 & 0.1237 & 1.4283 & 0.1820 & 0.0763 & 1.9550 & 0.0476 & Res \\
\hline Residuals & 54 & 0.0866 & & 0.0390 & & & & \\
\hline \multirow[t]{2}{*}{ Total } & 80 & \multirow{2}{*}{\multicolumn{3}{|c|}{ Transf.: none; Cochran's test: ns }} & & & & \\
\hline & & & & & \multicolumn{3}{|c|}{ Transf.: none; Cochran's test: ns } & \\
\hline
\end{tabular}

identity has to be taken into account in implementing monitoring actions (i.e. 'ecological status' assessment, sensu Water Framework Directive of the European Union). C. amentacea var. stricta is a key species in maintaining habitat complexity and species diversity in Mediterranean Sea low shores. This species is protected by the Bern Convention (Council of Europe 1979), but current protection measures do not seem sufficient to stop its current retreat (Thibaut et al. 2005) and we recommend that further conservation actions (i.e. restoration of lost substrata by transplantation, Susini et al. 2007) be seriously considered.

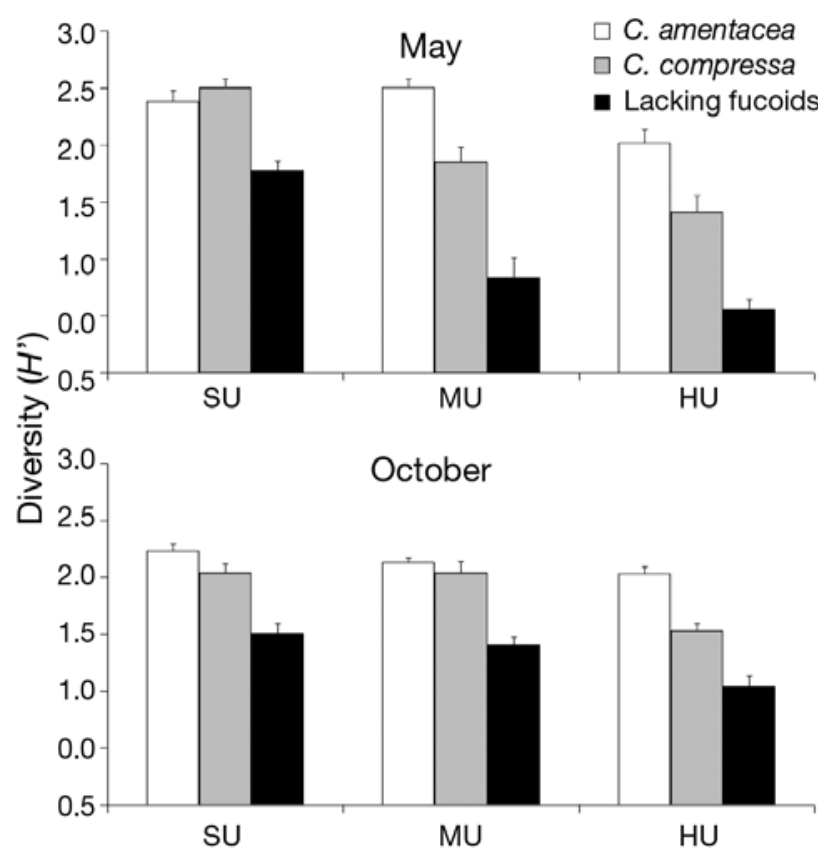

Fig. 6. Shannon-Wiener diversity index $\left(H^{\prime}\right)$ along the urban gradient in the 3 habitats. Abbreviations as in Fig. 2 (error bars: SE)
Acknowledgements. We thank L. Airoldi and 2 anonymous referees for comments that highly improved the manuscript, M. J. Anderson for help in statistical analyses, E. Ballesteros and D. Serio for identification of algae and S. Bava, R. Bullo, G. Passeron Seitre for their help in the field or in the laboratory.

\section{LITERATURE CITED}

Airoldi L (1998) Roles of disturbance, sediment stress, and substratum retention on spatial dominance in algal turf. Ecology 79:2759-2770

Airoldi L (2003) The effects of sedimentation on rocky coast assemblages. Oceanogr Mar Biol Annu Rev 41:161-236

Airoldi L, Beck MW (2007) Loss, status and trends for coastal marine habitats in Europe. Oceanogr Mar Biol Annu Rev 45:347-407

Anderson MJ (2001) A new method for non-parametric multivariate analysis of variance. Austral Ecol 26:32-46

Anderson MJ (2003) PCO: a FORTRAN computer program for principal coordinate analysis. Department of Statistics, University of Auckland

Anderson MJ, Millar RB (2004) Spatial variation and effects of habitat on temperate reef fish assemblages in northeastern New Zealand. J Exp Mar Biol Ecol 305:191-221

Arèvalo R, Pinedo S, Ballesteros E (2007) Changes in the composition and structure of Mediterranean rocky-shore communities following a gradient of nutrient enrichment: descriptive study and test of proposed methods to assess water quality regarding macroalgae. Mar Pollut Bull 55: 104-113

Ballesteros E (1988) Estructura y dinámica de la communidad de Cystoseira mediterranea Sauvageau en el Mediterráneo noroccidental. Investig Pesq 52:313-334

Ballesteros E (1989) Production of seaweeds in northwestern Mediterranean marine communities: its relation with environmental factors. Sci Mar 53:357-364

Ballesteros E, Sala E, Garrabou J, Zabala M (1998) Community structure and frond size distribution of a deep water stand of Cystoseira spinosa (Phaeophyta) in the northwestern Mediterranean. Eur J Phycol 33:121-128

Ballesteros E, Hereu B, Zabala M, Alcoverro T, Garrabou J, Sala E (2003) Rapport Mission Scandola - Cystoseira 2000. Trav Sci Parc Natl Rég Corse Rés Natl 260:95-114

Ballesteros E, Torras X, Pinedo S, García M, Mangialajo L, de 
Torres M (2007) A new methodology based on littoral community cartography for the implementation of the European Water Framework Directive. Mar Pollut Bull 55: $172-180$

Barceló MC, Gallardo T, Gómez A, Pérez-Ruzafa I, Ribera MA, Rull J (2000) Fucales. In: Gomez Garreta A (ed) Flora phycologica iberica, Vol. 1. Universidad de Murcia, Murcia

Benedetti-Cecchi L, Cinelli F (1992) Canopy removal experiments in Cystoseira dominated rockpools from the western coast of the Mediterranean (Ligurian Sea). J Exp Mar Biol Ecol 155:69-83

Benedetti-Cecchi L, Nuti S, Cinelli F (1996) Analysis of spatial and temporal variability in interactions among algae, limpets and mussels in low-shore habitats on the west coast of Italy. Mar Ecol Prog Ser 144:87-96

Benedetti-Cecchi L, Bulleri F, Cinelli F (2000) The interplay of physical and biological factors in maintaining mid-shore and low-shore assemblages on rocky coasts in the northwest Mediterranean. Oecologia 123:406-417

Benedetti-Cecchi L, Pannacciulli F, Bulleri F, Morchella PS, Airoldi L, Relini G, Cinelli F (2001) Predicting the consequences of anthropogenic disturbance: large scale effects of loss of canopy algae on rocky shores. Mar Ecol Prog Ser 214:137-150

> Bulleri F, Benedetti-Cecchi L, Acunto S, Cinelli F, Hawkins SJ (2002) The influence of canopy algae on vertical patterns of distribution of low shore assemblages on rocky coasts in the northwest Mediterranean. J Exp Mar Biol Ecol 267: 89-106

Clarke KR, Gorley RN (2006) Primer v6. PRIMER-E. Plymouth

> Clayton MN (1990) The adaptive significance of life history characters in selected orders of marine brown macroalgae. Aust J Ecol 15:439-452

> Connell SD (2005) Assembly and maintenance of subtidal habitat heterogeneity: synergistic effects of light penetration and sedimentation. Mar Ecol Prog Ser 289:53-61

Council of Europe (1979) Convention on the conservation of European wildlife and natural habitats (Bern Convention, no. 104). Council of Europe, Strasbourg

Dayton PK (2003) The importance of the natural sciences to conservation. Am Nat 162:1-13

Dayton PK, Sala E (2001) Natural history: the sense of wonder, creativity and progress in ecology. Sci Mar 65: 199-206

> Dethier MN, Graham ES, Cohen S, Tear LM (1993) Visual versus random-point percent cover estimations: 'objective' is not always better. Mar Ecol Prog Ser 96:93-100

Eriksson BK, Johansson G, Snoeijs P (2002) Long-term changes in the macroalgal vegetation of the inner Gullmar Fjord, Swedish Skagerrak coast. J Phycol 38:284-296

Giaccone G (1993) The vertical zonation along the phytal system in the Mediterranean Sea and the effects of municipal and industrial waste-water disposal on phytobenthos communities. Proc 5th OPTIMA Meeting, Istanbul, p 47-56.

Giaccone G, Bruni A (1973) Le Cistoseire e la vegetazione sommersa del Mediterraneo. Atti Ist Veneto Sci, Lett ed Arti Venezia 131: 59-103

Guiry MD, Guiry GM (2007) AlgaeBase version 4.2. National University of Ireland, Galway. www.algaebase.org; searched on 02 May 2007

Hereu B (2006) Depletion of palatable algae by sea urchins and fishes in a Mediterranean subtidal community. Mar Ecol Prog Ser 313:95-103

> Jenkins SR, Hawkins SJ, Norton TA (1999a) Direct and indirect effects of a macroalgal canopy and limpet grazing in structuring a sheltered inter-tidal community. Mar Ecol Prog Ser 188:81-92

Jenkins SR, Hawkins SJ, Norton TA (1999b) Interaction

Editorial responsibility: Victor de Jonge,

Hull, UK between a fucoid canopy and limpet grazing in structuring a low shore intertidal community. J Exp Mar Biol Ecol 233: 41-63

Kennelly SJ (1987) Inhibition of kelp recruitment by turfforming algae and consequences for an Australian kelp community. J Exp Mar Biol Ecol 112:49-60

Mangialajo L, Ruggieri N, Asnaghi V, Chiantore MC, Povero $\mathrm{P}$, Cattaneo Vietti R (2007) Ecological status in the Ligurian Sea: the effect of coastline urbanisation and the importance of proper reference sites. Mar Pollut Bull 55:30-41

Meese RJ, Tomich A (1992) Dots on the rocks: a comparison of percent cover estimation methods. J Exp Mar Biol Ecol 165:59-73

Moore P, Hawkins SJ, Thompson RC (2007) Role of biological habitat amelioration in altering the relative responses of congeneric species to climate change. Mar Ecol Prog Ser 334:11-19

> Munda IM (1993) Changes and degradation of seaweed stands in the northern Adriatic. Hydrobiologia 260-261: 239-253

Pérès JM, Picard J (1964) Nouveau manuel de bionomie benthique de la mer Méditerranée. Recl Trav Stn Mar Endoume Fac Sci Mars 31:5-137

Pinedo S, Garcia M, Satta MP, de Torres M, Ballesteros E (2007) Rocky-shore communities as indicators of water quality: a case study in the northwestern Mediterranean. Mar Pollut Bull 55:126-135

Pizzuto F, Presti C, Serio D (1995) Struttura e periodismo di un popolamento a Cystoseira amentacea Bory v. stricta Montagne (Fucales, Fucophyceae) del litorale catanese. Boll Acad Gioenia Sci Nat 28:23-43

Reed DC, Foster MS (1984) The effect of canopy shading on algal recruitment and growth in a giant kelp forest. Ecology 65:937-948

Scheffer M, Carpenter S, Foley JA, Folke C, Walkerk B (2001) Catastrophic shifts in ecosystems. Nature 413:591-596

Schiel DR, Wood SA, Dunmore RA, Taylor DI (2006) Sediment on rocky intertidal reefs: effects on early post-settlement stages of habitat-forming seaweeds. J Exp Mar Biol Ecol 331:158-172

Serio D, Alongi D, Catra M, Cormaci M, Furnari G (2006) Changes in the benthic algal flora of Linosa Island. Bot Mar 49:135-144

Shannon CE, Weaver W (1949) The mathematical theory of communication. University of Illinois Press, Urbana

Soltan D, Verlaque M, Boudouresque CF, Francour P (2001) Changes in macroalgal communities in the vicinity of a Mediterranean sewage outfall after the setting up of a treatment plant. Mar Pollut Bull 42:59-70

Steneck RS, Graham MH, Bourque BJ, Corbett D, Erlandson JM, Estes JA, Tegner MJ (2002) Kelp forest ecosystems: biodiversity, stability, resilience and future. Environ Conserv 29:436-459

Susini ML, Mangialajo L, Thibaut T, Meinesz A (2007) Development of a transplantation technique of Cystoseira amentacea var. stricta and Cystoseira compressa. Hydrobiologia 580:241-244

Thibaut T, Pinedo S, Torras X, Ballesteros E (2005) Long-term decline of the populations of Fucales (Cystoseira spp. and Sargassum spp.) in the Albères coast (France, northwestern Mediterranean). Mar Pollut Bull 50:1472-1489

Underwood AJ (1997) Experiments in ecology: their logical design and interpretation using analysis of variance. Cambridge University Press, Cambridge

Vogt H, Schramm W (1991) Conspicuous decline of Fucus in Kiel Bay (Western Baltic): what are the causes? Mar Ecol Prog Ser 69:189-194

Submitted: December 12, 2006; Accepted: December 25, 2007 Proofs received from author(s): April 9, 2008 